さて本諭にもどり．大気圈外航行を考えて見よう。 大気は地球中心加ら $3,000 \mathrm{~km} く$ くらいまて，大部分は 対流圏の $16 \mathrm{~km}$ 内にあるが，とにかくある国家グル 一プは大気圈外航行技術を開発し，他のある国家グル ープはしなかったとしよう．前者が後者と競うとき， 断然有利であることは確かてある。このときまた英国 とスペインとの間の状態が生じる.

ここで困難な問題は国民たちに，この新技術を開発 する多額の経費を投じことを納得させることであ る. しかも金鉱やウラニウム, 絹や查料を求めるため ではなくて，単に新しい技術，他国家群に対抗する技 術を筑くため，とあっては国民の理解を得ることは困 難というすのである. しかし，理解を得なければなら ぬし，米国ではなお引き続き理解を求めるよう努力し ている.

つぎの問題は経費の巨額さにある。すはやライト兄 弟に頼ることは不可能で, 全国家を挙げて研究所と し，全国民が冓かなければならぬ，その結果として得 られるものは月または遊星へ行く人工街星である.月 に人間を運んで何になるかという人が多いが，実はそ れ自体が重要なことでなく，その技術が重要なのであ る. その技街を持つことは, 対抗者より良い電子エ
学，材料，装置を持つことで，その成果はまた技術資 源にフィードバックされる. またフィードパックされ る分野は他の部門に及ふ:

この新しい技街, 宇宙工学の中でもっとも重要な部 門は推進で，たとえば電気推進やこれに開連する電磁 流体力学などは興味深い。私の専門分野としては, 制 御であるが，これは従来それはど困難とは考えられな かった．雑誌や映画てロケットの発射状況をよく知っ ていると思らが，制御状態はよく見えないのである.

私の研究所はアポロ計画と乎ぶ作業の誘導システム の責任を負っている.これは月に 3 人の人間を運ぶ のである、私自身この1人になりたいと思っているほ ど重要な計画である.このシステムは慣性および光学 誘導で, 加地上のステーションから追跡され，その 結果はロケットに逆送されて予測に使われる.この際 もちろん計算機が使われる. アナログ計算機とディジ タル計算機の比較はよく議論された. ディジタル計算 機は最近 15 年間に第くべき発達を遂げたが, 迅速か つ困難な問題を解き得る反面高価である. しかしそ そ れがどこまで発達するか予想はできないから，もしも っと安価になれば，ロケット以外にも公い用途がある 亏.

\title{
慣性誘導法の計器 装備*
}

\section{S. DRAPER}

慣性誘導法では，重力および加速度を恒星空間に関 連して測定する必要がある.このいわゆる惯性空間に 固定した座標系を作るものがプラットフォームて，常 にジャイロによって安定される.シシャイロは恒星空間 に対する回転角によって信号，たとえば電圧を発生し て安定制御を行なう. 回転角の精度は地表で 1 海里の 精度を得ようとすれば 抔度 $1^{\prime}$ 以下、ジ+イロにとっ ては弧度 $5^{\prime \prime}$ の測定が可能でければならぬ. プラッ

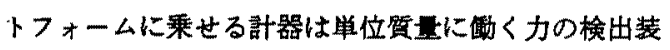
置 (specific force receiver, SFR)すなわち加速度計で ある. われわれはジャイロを 3 個使い，加速度計はも ちろん 3 個を必要とするか， その誴差は $10^{-5} \sim 10^{-6}$ $g$, 最大測定値は $10 \sim 100 g$ であるから, 要求は極め てきびしい.

ジャイロは浮遊型を使うことが多いが，そのとき部 品は大部分ベリリウム製である、ベリリウムは強度が

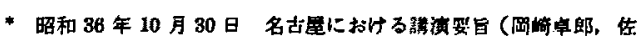

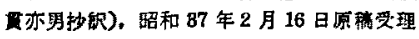

大きくて軽く，比重は約 2 で，浮遊液体は Fluorolube (米国 Hooker Electrochemical Corp.の商品名，潤滑 油の炭菜を弗素で圆換したるの)でやはり比重䄪2て あるから，中性の浮遊が可能である.ジャイ駆動の 同期電動機（ヒステリシス型）へ電流を通しる等線も ベリリウムが使われる.フロートが方向によって用性 を異にするときは anisoelasticity error (非等方弾性誤 差）と称する誤差が生ずるので，外部から調整可能な 補僙装置をつける。

信号発生汥置は Microsyn で，それをつけたフロー 卜は通常運転時にケースに対して弧度数秒回転するに すぎない.フロート他端にはマイクロシン・トルク発 生装置をとりつけ，これら2 装置間には，回転軸を軸 受けから浮かせる magnetic suspension を持つ。浮遊 支持は高加速度，衙擊をよく吸収する，機珹加工およ び清浄は極度まで要求され，粘性トルク以外の不礁 定トルクは 1 dyne. cm の干分の一以下に保必要が ある. 